\title{
A Gap Between Children's Rights and Curricular Content in Health, Social Care, and Teacher Education Programs: An Exploratory Cross-Sectional Study
}

\author{
Kari Almendingen (iD) \\ Marit Tørstad ${ }^{2}$ \\ Bente Sparboe-Nilsen (D) \\ Lisbeth Gravdal Kvarme (D) \\ Jurate Šaltytė Benth ${ }^{3,4}$ \\ 'Department of Nursing and Health \\ Promotion, Faculty of Health Sciences, \\ OsloMet - Oslo Metropolitan University, \\ Oslo, Norway; ${ }^{2}$ The Children's House, \\ Oslo Police District, Oslo, Norway; \\ ${ }^{3}$ Institute of Clinical Medicine, Campus \\ Ahus, University of Oslo, Blindern, \\ Norway; ${ }^{4}$ Health Services Research Unit, \\ Akershus University Hospital, Lørenskog, \\ Norway
}

Correspondence: Kari Almendingen Department of Nursing and Health Promotion, Faculty of Health Sciences, Oslo Metropolitan University, Oslo, Norway

Email kalmendi@oslomet.no

\begin{abstract}
Introduction: Exposure to child maltreatment is a social and public health challenge that will require interprofessional collaboration to overcome. Evidence indicates that professional students in health, social care, and teacher education programs receive inadequate training in recognizing and responding to child maltreatment. The aims are to 1) assess the extent to which these students found that their uniprofessional education and a large-scale interprofessional learning (IPL) course had taught them about children in general, children's rights, and vulnerable/at-risk children; and 2) explore differences in student responses according to age and educational background.
\end{abstract}

Methods: A cross-sectional study. Students $(\mathrm{n}=2811)$ completed questionnaires prior to or after IPL courses held in 2019 and 2020 (hybrid case-based, small-group, on-campus courses targeting children, young people, and their families as end users).

Findings: The majority ( $>90 \%)$ agreed that it was important to learn about child-related topics. Only $4.3 \%$ disagreed that it was important to learn about vulnerable/at-risk children. Health and social care students enhanced their insight into all the child-related topics $(\mathrm{p}<0.001)$ after the IPL course. Teacher education and child welfare students reported decreased insight into children in general $(p<0.001$ in 2019 and $p=0.008$ in 2020) but increased insight into vulnerable/at-risk children in 2020 ( $\mathrm{p}=0.001)$. According to stratified analyses, there was a significantly increased insight into all child-related topics among physiotherapy and Mensendieck physiotherapy students $(\mathrm{p}<0.001)$, decreased insight into children in general among teacher education students $(\mathrm{p}<0.02)$, and increased insight into vulnerable/at-risk children among teacher education students $(\mathrm{p} \leq 0.001)$ in both 2019 and 2020. Age was of minor importance. The response rates ranged from $16.0 \%$ to $36.0 \%$.

Conclusion: After the IPL course, the health and social care students significantly enhanced their insight into child-related topics, whereas the students in teacher education and child welfare gained increased insight into vulnerable/at-risk children.

Keywords: children, student, education, ACE, child maltreatment, abuse, social worker

\section{Plain Language Summary}

- Lack of education and relevant pre-service training in higher education has been suggested as an explanation for why professionals who are legally required to report child maltreatment often fail to do so.

- Child maltreatment is a social and public health challenge and a politically prioritized task. It has been linked to a variety of short- and long-term health impacts. Professional 
background may lend itself to earlier identification of the signs and symptoms of child abuse or violence.

- This study reveals a gap between child-related policies and curricular content in health, social care, and teacher education programs.

- The study supports an interprofessional approach because candidates from health, social care, and teacher education are expected to work with interprofessional competence when dealing with children, young people, and their families.

- This study confirms that health, social care, and teacher education programs have been slow to align curricula with new laws on child maltreatment and with the United Nations Convention on the Rights of the Child. That is long overdue.

\section{Introduction}

Child maltreatment is a social and public health concern around the world that has well-established impacts on and costs to children, families, and society. ${ }^{1-13}$ Several definitions of child maltreatment exist, but the World Health Organization's (WHO) defines child maltreatment as:

all types of physical and/or emotional ill-treatment, sexual abuse, neglect, negligence, and commercial or other exploitation, which results in actual or potential harm to the child's health, survival, development or dignity in the context of a relationship of responsibility, trust or power. ${ }^{12}$

Children who are vulnerable or at-risk are a complex group $^{14,15}$ that includes children with disabilities, ${ }^{16}$ children living in institutions, ${ }^{17}$ children with parents unable to care for the child, ${ }^{18,19}$ with parents who undergo divorce, ${ }^{9,20}$ with parents in prison, ${ }^{21}$ with parents who have substance abuse problems, ${ }^{18,22}$ and poverty. ${ }^{9,23}$ Children in vulnerable situations face the highest risk of violation of their rights. ${ }^{24}$ This causes many of these children to adopt risky health and social behaviors, such as drinking, overeating, smoking, and sexual promiscuity, as a means of coping with the traumas they have experienced. ${ }^{10,12,13}$ These risky behaviors have been shown to generally translate into poor health and early death. $^{8,15,25}$

According to the WHO, about 300 million children worldwide aged 2-4 years regularly suffer physical punishment and other forms of violence, and one in five women and one in 13 men under the age of 20 have been victims of some form of forced sexual abuse. ${ }^{12}$ In a meta-analysis, the global prevalence of various types of child maltreatment was estimated at $22.6 \%$, and prevalence varied significantly between countries. ${ }^{26} \mathrm{~A}$ review from the Nordic countries found differences in the prevalence of child maltreatment between countries. ${ }^{27}$ This review suggested that the prevalence of witnessing domestic violence was in the range of $7-12.5 \%$, of severe physical abuse in the range of 3-9\%, and of child sexual abuse in the range of $0.2-1.2 \% .{ }^{27}$ In $2020,4 \%$ of Norwegian children aged 0-22 years had measures from the Child Welfare Services. ${ }^{28}$ A Norwegian report stated that $20 \%$ of adolescents have experienced physical violence and that $20 \%$ have experienced psychological violence from their parents. ${ }^{13}$ Most of the participants that had been subjected to one type of violence or abuse had also experienced other forms of violence or abuse, and girls had more often been exposed to several types of violence than had boys. ${ }^{13}$

Health and social personnel and teachers are legally mandated to report suspicion of any form of child maltreatment to the Child Welfare Services. ${ }^{29-32}$ However, public supervision of child welfare, health, and social services in Norway has documented that professionals often do not behave in a manner that is consistent with the spirit of the Norwegian law. ${ }^{33,34}$

Lack of child-related education and pre-service training has been suggested as an explanation for why professionals who are legally mandated to report child maltreatment often fail to do so. ${ }^{35,36}$ Signs of mistreatment are often diffuse, and the topic of children and maltreatment is variously defined, especially in those countries in which child labor is a traditional practice. ${ }^{12}$ Understanding and interventions differ, as do national politics. ${ }^{7}$ The lack of training in teacher education programs, which was highlighted many years ago, may result in teachers who are not entirely aware of the indicators of child maltreatment or how to report suspected maltreatment. ${ }^{1,37-48}$ Similarly, a review from Canada indicates that health and social care students receive inadequate training in recognizing and responding to child maltreatment. ${ }^{49}$ Child-related content in general nursing curricula varies considerably across Europe, which may be due to the lack of a European standard or to a lack of focus on children in general nursing curricula. $^{50}$

Many children have several risk factors at the same time and need coordinated help in multiple arenas and within multiple specialized services. ${ }^{51}$ A recent Norwegian law states that all professionals working with 
children are required to increase interprofessional collaboration (IPC) between the services. ${ }^{51}$ The intention is to bridge the distance between the different welfare services, to reduce inadequate coordination and IPC, and to prevent pulverization of liability. Interprofessional learning (IPL) has been suggested to achieve improved IPC. ${ }^{52}$ IPL facilitates students from different professions learning with, from, and about each other in order to improve IPC. ${ }^{52}$ Currently, students from education, health, and social study programs are mainly educated in trajectories that are built on different disciplinary professional identities, cultures, traditions, and syllabi, all of which may act as barriers to professional collaboration and teamwork. ${ }^{53}$ Knowledge boundaries between different professions in the welfare services include differences in legislation and duties of confidentiality, as well as different definitions, cultures, curricula, procedures, and knowledge bases. ${ }^{51}$ An ongoing cross-sectional IPL study at Oslo Metropolitan University (OsloMet) ${ }^{54}$ made it possible to investigate the preparedness of students in health, social care, and teacher education to deliver services to children with normal and not normal childhood experiences. When IPL is expanded beyond health care to include teachers and child welfare students, the latter will contribute a higher knowledge base on children, young people, and their families. Bronfenbrenner's ecological systems theory ${ }^{55}$ is used to better understand the context of the child's situation, how the interaction between the different system levels affects the child, and the outcome of the intervention. ${ }^{54}$ As previously described, ${ }^{54}$ we applied social constructivist theory and a case-based, small-group learning approach in the IPL course, ${ }^{56}$ which is considered a useful strategy for facilitating IPL. ${ }^{56-58}$ Although there is an identified need for educators to better prepare students for IPC, little has been reported on disciplinary differences in IPL preparedness with respect to unequal knowledge bases concerning children and maltreatment of children; thus, little has been reported on their preparedness for IPC targeting children, young people, and their families. ${ }^{51}$

The aims of this study are to:1) assess the extent to which students of pre-service teacher education, health, and social care education found that their uniprofessional education and a large-scale IPL course had taught them about children in general, children's rights, and vulnerable/ at-risk children (hereafter referred to as child-related topics); and 2) explore differences in student responses according to age and educational background.

\section{Materials and Methods}

\section{Setting}

The data for this quantitative cross-sectional study consisted of responses from undergraduate students subject to compulsory participation in a large-scale blended IPL course (course name: INTER1100) at OsloMet in Norway, which has previously been described in detail. $^{54,59-61}$ The IPL course is a part of an educational intervention entitled INTERACT (Interprofessional Interaction with Children and Young People) at OsloMet that aims to meet society's demands for better coordination of services in relation to children and young people, better interaction between professionals, and better cooperation between children/young people and professionals. ${ }^{61}$ The project extended IPL beyond health and social care to include teacher education and child welfare students because these professions must collaborate in real-life situations involving children, young people, and their families. Data were collected before (pre) and after (post) course delivery in both 2019 and 2020 (ie before the lockdown in March 2020 due to the COVID-19 pandemic in Norway).

\section{Participants}

Undergraduate students $(\mathrm{n}=1401$ in 2019 and $\mathrm{n}=1410$ in 2020) were enrolled in the following education programs: Early Childhood Education, Primary and Lower Secondary Teacher Education, Teacher Education in Art and Design (not attaining in 2019), Physiotherapy, Mensendieck Physiotherapy, Nursing, Social Work, Child Welfare, and Occupational Therapy. All of the nursing students and $49 \%$ of the physiotherapy students were second-year students, while the others were firstyear students in 2019. In 2020, only the nursing students were second-year students. ${ }^{61}$ The nursing students were located on the Kjeller campus, the others on the Pilestredet campus. The enrolled students were divided into pre-defined IPL groups, each consisting of eight students from the health, social care, and teacher education programs. The IPL groups therefore consisted of students with different knowledge about children. The IPL course was compulsory; thus, no inclusion criteria were applied.

Supervisors $(n=13)$ were recruited from among the staff, master students, and professionals working in the field and were either educated as teachers $(n=9)$ or as health personnel (one from Nursing, two from 
Physiotherapy, and one from Mensendieck Physiotherapy). ${ }^{60}$

\section{Blended Small-Group Learning Course}

The provision of the 2020 IPL course was based on the 2019 IPL course. ${ }^{54}$ The required coursework included participation in a two-day seminar and submission of an IPL group assignment. The seminar days were structured as a combination of face-to-face IPL group discussions on campus and the use of digital learning materials provided by the learning management system (LMS) Canvas. The latter included case-based learning material (produced by user organizations, employers, and public authorities) and mini lectures (produced by staff and colleagues from the working field) that were divided into different sections. Following a flipped classroom approach, digital learning material was made available through LMS Canvas prior to the IPL course. ${ }^{62}$ The students were introduced to free online learning material about parenthood, children's development, and interaction between adults and children that was provided by the government, ${ }^{63}$ and they also had access to specially prepared flipped classroom video lectures about developmental psychology. They were also introduced to a freely available digital platform for collaboration and competence sharing between municipalities, hospitals, and educational institutions (Kompetansebroen. no) and to a concrete example from Fauske municipality on how to observe children in kindergarten and school. Articles 2-5, 7, 17, 23, 30 and 31 of the Convention on the Rights of the $\mathrm{Child}^{3}$ were presented in video clips provided by the Ombudsperson for Children. To understand how the inherent qualities of children and their environments interact and influence growth and development, participants were taught Bronfenbrenner's ecological systems theory. ${ }^{55}$

During the first seminar day, the students learned about children's rights with the following learning objective: "is familiar with the Ombudsperson for Children's role and responsibilities"; "is capable of explaining the Convention on the Rights of the Child"; and "is familiar with the right to participation and co-determination established by the Ombudsperson for Children." The students were instructed to watch a video clip about the role of the Ombudsperson for Children and read through the rights poster (rights at different ages) published by the government. ${ }^{64}$ They discussed the following questions: "What have you learned about the legal basis that governs children's participation, such as the right to education?"; "Why are there different legal bases for health, social work, kindergarten, and school?"; and "Do you know any situations in which children's rights may be violated?" The session was concluded with a one-minute paper. The students were encouraged to repeat the learning objectives, list keywords individually, share one of their keywords with the rest of the group, and explain why they chose it.

During the second seminar day, students learned about interprofessional work among children, young people, and their families. The digital learning material highlighted that although most children have good lives in Norway, IPC between child welfare, health, and social services unfortunately does not work as it should. In 2019, the seminar emphasized serious failures in the handling of cases that led to children being exposed to violence, sexual abuse, and neglect. The learning objectives were: "Introductory knowledge of IPC regarding children"; "Introductory knowledge of the consequences of a lack of collaboration between the professions"; and "Introductory knowledge of ethical dilemmas, the duty to provide information, and the duty of confidentiality as obstacles to IPC." The students were given examples of measures that have been initiated in the municipalities to improve IPC, such as a video clip ${ }^{65}$ about a collaboration initiated through a joint assignment from multiple ministries that focuses on vulnerable children aged $0-24$ years and their families. ${ }^{65}$ The video clip portrays a child with many challenges, which means that multiple services, sectors, and people are in contact with the child and the child's family. The aim $^{65}$ is the provision of a service that is both better coordinated and more integrated. The students also discussed a specially prepared video clip from Lørenskog municipality that gave an example of a real-life IPC targeting children, young people, and their families that focuses on students who have quit school. One of the questions the IPL groups were asked to discuss was: "If IPC is the solution, then what's the problem?". During the course, they learned about children as next of kin, ${ }^{66}$ diversity (social and cultural) and multilingualism (only in 2019), tolerance, observation, new research findings from the Ungdata surveys, ${ }^{67}$ and the Ombudsperson for Children.

\section{Online Evaluation Survey}

No suitable national or international questionnaire had been developed and/or validated in Norway. Hence, questions for the present study had to be specially prepared as part of larger questionnaires targeting students and supervisors. ${ }^{54}$ Questionnaire-based quantitative research 
using an anonymous self-administrated online survey (Nettskjema) ${ }^{68}$ and previous research ${ }^{54,59,69}$ was used to develop the questionnaires. Nettskjema is a tool for designing and conducting online surveys with customized features for research. It is easy to use, and respondents can submit answers from a browser on a computer, mobile phone, or tablet. ${ }^{68}$ After the questionnaires were tested and commented on by university colleagues (academic and administrative) and by one student, they were revised accordingly. For the present study, the students were asked the following closed questions after delivery of the IPL course in both 2019 and 2020 (post-2019, n=507 and post2020, $n=363$ ):

To what extent do you feel that the IPL course has given you better academic insight into children in general, vulnerable/at-risk children, and children's rights?

Two separate closed questions were asked before the IPL course in 2020 (pre-2020, $\mathrm{n}=454$ ):

To what extent have you learned about the following (ie children in general, vulnerable/at-risk children, and children's rights) as part of your degree?

and

In the upcoming IPL course, to what degree do you think it is important to learn about children in general, vulnerable/at-risk children, and children's rights?

A closed question for the supervisors was also included after the IPL course in $2020(\mathrm{n}=13)$ :

To what extent do you feel that the IPL course has given the students better academic insight into children in general, vulnerable/at-risk children, and children rights?

The participants could respond on a scale from 0 ("completely disagree") to 5 ("completely agree"). Separate questions were asked about children as next of kin. ${ }^{66}$ In Norwegian legal terms, a "child" means any person under 18 years of age, ${ }^{3}$ and the term "young people" is often used for people up to 25 years of age. ${ }^{31}$ In this paper, we refer to children and young people as "children." The student questionnaires (pre/post) were provided as an internet link embedded in the students' LMS, whereas the supervisor (post) questionnaire was distributed via email. One reminder was sent to increase the response rate.

\section{Data Analysis}

Frequencies and percentages were used to present the data. As the distribution of responses was skewed, the responses were dichotomized to either "agree" (score 3-5) or "disagree" (score 0-2). A z-test for proportions was applied to compare the dichotomized pre- and post-responses. To assess the change between the dichotomized pre- and postcourse responses from 2019 and 2020, a logistic regression model with a time dummy (2019 or 2020), a period dummy (pre or post), and an interaction between them was estimated. Analyses were further stratified by study programs dichotomized to either "teacher education and child welfare" (consisting of Early Childhood Education and Care, Primary and Lower Secondary Teacher Education, Child Welfare, and Teacher Education in Art and Design, since they only target children as end users) or "health and social care" (consisting of Physiotherapy, Mensendieck Physiotherapy, Nursing, Social Work, and Occupational Therapy, as they target all age groups as end users) by program as a nine-category variable, and by age, dichotomized to less than 25 or more than 25 years. Sensitivity analyses assuming that the scale was continuous (0-5) were performed by applying an independent samples $t$-test instead of a z-test for proportions. All tests were two-sided, and the results with p-values below 0.05 were considered statistically significant. Due to the exploratory nature of the study, no adjustment was made for multiple hypothesis testing. All statistical analyses were performed using the Statistical Package for the Social Sciences (SPSS) v27.

\section{Ethics}

This study followed the Ethical Guidelines for Research published by Oslo Metropolitan University (OsloMet), ${ }^{70}$ which are based on the Act relating to Universities and University Colleges, on the Act relating to Ethics and Integrity in Research and pursuant regulations, and on the ethical norms prepared by the Norwegian National Committees for Research Ethics. According to the Norwegian Centre for Research Data (NSD), ${ }^{71}$ the study was considered completely anonymous, as no sociodemographic information beyond the participants' age and gender was included; hence, the study was not subject to reporting requirements and should not be reported to the Norwegian Regional Ethics Committee (NSD reference number 741649). In accordance with ethical guidelines, ${ }^{70}$ the data were collected through an anonymous online 
survey using Nettskjema. ${ }^{68}$ All the participants were above 18 years of age and were provided written information about the study beforehand in LMS Canvas. The voluntariness and anonymity of the participants were emphasized, and the participants were informed about the purpose of the study and how the data would be used. Answering the questionnaire was considered informed consent to participate. The study complies with the Declaration of Helsinki.

\section{Results}

\section{Demographic Characteristics}

Students in all programs included in this study answered questionnaires. Response rates were $16.0 \%$ (pre-course 2019), 36.0\% (post-course 2019), 32.2\% (pre-course 2020), and $25.8 \%$ (post-course 2020) (Table 1). Among the students, 56.6\% (pre-course 2019), 48.3\% (post-course 2019), $43.8 \%$ (pre-course 2020), and 46.0\% (post-course 2020) were taking health and social care education programs.

Table I Characteristics of Students in a Large-Scale Blended Interprofessional Learning (IPL) Course Delivered in 2019 (Post-Course 2019) and in 2020 (Pre- Course and Post-Course 2020). Numbers are Stated as Frequencies and Percentages

\begin{tabular}{|c|c|c|c|c|}
\hline Variable & $\begin{array}{l}\text { Pre-Course } 2019^{a} \\
(n=221)\end{array}$ & $\begin{array}{l}\text { Post-Course } 2019^{a} \\
(n=507)\end{array}$ & $\begin{array}{l}\text { Pre-Course } 2020 \\
(n=454)\end{array}$ & $\begin{array}{l}\text { Post-Course } 2020 \\
(n=363)^{a}\end{array}$ \\
\hline \multicolumn{5}{|l|}{ Age } \\
\hline 21 years or younger & I0I (45.7) & $255(50.3)$ & $24 I(53.1)$ & $205(56.8)$ \\
\hline $22-24$ years & $65(29.4)$ & I $34(26.4)$ & $104(22.9)$ & $74(20.5)$ \\
\hline $25-27$ years & $22(10.0)$ & $63(12.4)$ & $42(9.3)$ & $34(9.4)$ \\
\hline$\geq 28$ years or older & $33(14.9)$ & $55(10.8)$ & $67(14.8)$ & $48(13.3)$ \\
\hline \multicolumn{5}{|l|}{ Study programs } \\
\hline Nursing & $25(11.3)$ & $50(9.9)$ & $47(10.4)$ & $35(9.6)$ \\
\hline Physiotherapy & $39(17.6)$ & $104(20.5)$ & $5 I(11.2)$ & $29(8.0)$ \\
\hline $\begin{array}{l}\text { Mensendieck Physiotherapy } \\
\text { Physiotherapy }\end{array}$ & $14(6.3)$ & $16(3.2)$ & $26(5.7)$ & I $8(5.0)$ \\
\hline Teacher Education ${ }^{\mathrm{b}}$ & $45(20.4)$ & I $33(26.2)$ & $108(23.8)$ & $92(25.3)$ \\
\hline $\begin{array}{l}\text { Teacher Education in Art and } \\
\text { Design }\end{array}$ & NA & NA & $28(6.2)$ & $23(6.3)$ \\
\hline $\begin{array}{l}\text { Early Childhood Education and } \\
\text { Care }\end{array}$ & $33(14.9)$ & 95 (I8.7) & $87(19.2)$ & $69(19.0)$ \\
\hline Occupational Therapy & $15(6.8)$ & $26(5.1)$ & $30(6.6)$ & $16(4.4)$ \\
\hline Child Welfare & $18(8.1)$ & $34(6.7)$ & $32(7.0)$ & $35(9.6)$ \\
\hline Social Work & $31(14.0)$ & $47(9.3)$ & $45(9.9)$ & $46(12.7)$ \\
\hline \multicolumn{5}{|l|}{ Age category } \\
\hline 25 years or younger & $101(45.7)$ & $389(76.7)$ & $345(76.0)$ & $279(77.3)$ \\
\hline 25 years or older & 65 (24.9) & II 8 (23.3) & $109(24.0)$ & $82(22.7)$ \\
\hline \multicolumn{5}{|l|}{ Study programme category } \\
\hline Health and social care ${ }^{c}$ & $22(56.6)$ & $245(48.3)$ & $199(43.8)$ & $167(46.0)$ \\
\hline Teaching and child welfare $^{d}$ & $33(43.4)$ & $262(5 \mid .7)$ & $255(56.2)$ & $196(54.0)$ \\
\hline
\end{tabular}

Notes: ${ }^{2} 2019$ and 2020 post-course demographic data has been previously published $(59,60,69)$ brimary and Lower Secondary Teacher Education. ${ }^{\mathrm{c} P h y s i o t h e r a p y,}$ Mensendieck Physiotherapy Physiotherapy, Nursing, Social Work and Occupational Therapy. ${ }^{\mathrm{d} E a r l y}$ Childhood Education and Care, Primary and Lower Secondary Teacher Education, Child Welfare, and Teacher Education in Art and Design.

Abbreviations: NA, no answer; Pre, questionnaire data before course delivery; Post, questionnaire data after course delivery. 


\section{Learned in Their Uniprofessional Education Programs}

Prior to the 2020 IPL course, $72.0 \%, 54.3 \%$, and $65.2 \%$ of students reported having learned (score 3-5) about children in general, vulnerable/at-risk children, and children's rights, respectively (Table 2). The majority $(>90 \%)$ agreed that it was important to learn about these topics as part of the IPL course. Only $4.3 \%$ disagreed (score 0-2) that it was important to learn about vulnerable/at-risk children.

\section{Learned in the IPL Course}

After the IPL course, $82.7 \%, 76.4 \%$, and $84.3 \%$ agreed (score 3-5) that they had been given better academic insight into children in general, vulnerable/at-risk children, and children's rights, respectively (Table 2).

After the courses in both 2019 and 2020, students reported a significant increase in their insight into children in general $(\mathrm{p}=0.021$ and $\mathrm{p}<0.001$, respectively), vulnerable/at-risk children (both $\mathrm{p}<0.001$ ), and children's rights (both $\mathrm{p}<0.001$ ) with no differences between them (Table 3).

\section{Variation in Student Responses According to Educational Background}

In both 2019 and 2020, the health and social care students significantly enhanced their insight into children in general, vulnerable/at-risk children, and children's rights (all $\mathrm{p}<0.001$ ) (Table 4). Among students in social care and teacher education programs, there was a significant decrease in insight into children in general $(p<0.001$ in 2019 and $p=0.008$ in 2020) and an increase in insight into vulnerable/at-risk children in $2020(\mathrm{p}=0.001)$ but no significant increase in 2019 (Table 4).

Analysis stratified by the education program as a ninecategory (Table 5) showed a significant increase in insight into children in general among students in Physiotherapy (p <0.001 in both 2019 and 2020), Mensendieck Physiotherapy $(p<0.001$ in both 2019 and 2020), Occupational Therapy ( $\mathrm{p}=0.017$ in 2019 but not in 2020), and Social Work ( $\mathrm{p}=0.009$ in 2019 but not in 2020). Among students of Teacher Education ( $\mathrm{p}=0.014$ in 2019 and $\mathrm{p}=0.016$ in 2020), Early Childhood Education $(p=0.001$ in 2019 but not in 2020), and Teacher Education in Art and Design ( $\mathrm{p}=0.008$ in 2020; not

Table 2 Distribution of Responses to Statements in a Large-Scale Blended Interprofessional Learning (IPL) Course Delivered in 2020 (On a Scale from 0 to 5, State How Much You Agree or Disagree with the Following Statements, Where 0 Means "Completely Disagree" and 5 Means "Completely Agree"). Numbers are Stated as Frequencies and Percentages

\begin{tabular}{|c|c|c|c|c|c|c|}
\hline \multirow[b]{2}{*}{ Questions: } & \multicolumn{6}{|l|}{ Scores } \\
\hline & 0 & $\mathbf{I}$ & 2 & 3 & 4 & 5 \\
\hline \multicolumn{7}{|c|}{ Pre-course 2020: As part of your degree, to what extent have you learned about $(N=454)$ : } \\
\hline Children in general & $26(5.7)$ & $37(8.1)$ & $64(14.1)$ & $91(20.0)$ & $117(25.8)$ & $119(26.2)$ \\
\hline Vulnerable/ at risk children & $47(10.4)$ & $69(15.2)$ & $92(20.3)$ & $121(26.7)$ & $67(14.8)$ & $58(12.8)$ \\
\hline Children's rights & $40(8.8)$ & $45(9.9)$ & $73(16.1)$ & $109(24.0)$ & $105(23.1)$ & $82(18.1)$ \\
\hline \multicolumn{7}{|c|}{ Pre-course 2020: In the upcoming ILP course, to what degree do you think it is important to learn about $(N=454)$ : } \\
\hline Children in general & $7(1.5)$ & $9(2.0)$ & $18(4.2)$ & $52(11.5)$ & $124(27.3)$ & $244(53.7)$ \\
\hline Vulnerable/at risk children & $6(1.3)$ & $3(0.7)$ & II (2.4) & $38(8.4)$ & $107(23.6)$ & $289(63.7)$ \\
\hline Children's rights & $7(1.5)$ & $7(1.5)$ & $24(5.3)$ & $53(11.7)$ & II 2 (24.7) & $25 I(55.3)$ \\
\hline \multicolumn{7}{|c|}{$\begin{array}{l}\text { Post-course 2020: As part of the IPL course, to what extent do you feel that you have given you a better academic insight int } \\
(\mathrm{N}=363) \text { : }\end{array}$} \\
\hline Children in general & $6(1.7)$ & $21(5.8)$ & $36(9.9)$ & $90(24.8)$ & $124(34.2)$ & $86(23.7)$ \\
\hline Vulnerable/ at risk children & $8(2.2)$ & $27(7.4)$ & $51(14.0)$ & $91(25.1)$ & $116(32.0)$ & $70(19.3)$ \\
\hline Children's rights & $4(1.1)$ & II (3.0) & $42(11.6)$ & $77(2 \mid .2)$ & $130(35.8)$ & $99(27.3)$ \\
\hline
\end{tabular}

Notes: aPre-data and post-data from 2019 were previously published $(59,69)$.

Abbreviations: Pre, questionnaire data before course delivery; Post, questionnaire data after course delivery. 
Table 3 Differences Between 2019 and 2020 in Change from Pre-Course to Post-Course in Proportion of Agreeing Students (Score 3-5)

\begin{tabular}{|c|c|c|c|}
\hline & 2019 & 2020 & 2019 vs 2020 \\
\hline \multicolumn{4}{|l|}{ Children in general } \\
\hline Pre, $\mathrm{N}$ & 220 & 454 & \\
\hline $3-5$, n (\%) & $136(6 \mid .8)$ & $327(72.0)$ & \\
\hline Post, N & 505 & 363 & \\
\hline $3-5, \mathrm{n}(\%)$ & $356(70.5)$ & $300(82.6)$ & \\
\hline \multicolumn{4}{|l|}{ Difference in change pre to post } \\
\hline Proportion 3-5 (\% (95\% Cl)) & 8.7 (I.I; I6.2) & $12.6(4.9 ; 16.3)$ & \\
\hline $\mathrm{P}$-value & $0.02 \mathrm{I}^{\mathrm{a}}$ & $<0.001^{\mathrm{a}}$ & $0.352^{b}$ \\
\hline \multicolumn{4}{|l|}{ Vulnerable/at risk children } \\
\hline Pre, $\mathrm{N}$ & 220 & 454 & \\
\hline $3-5, \mathrm{n}(\%)$ & $102(46.4)$ & $246(54.2)$ & \\
\hline Post, N & 503 & 363 & \\
\hline $3-5, \mathrm{n}(\%)$ & $339(67.4)$ & $277(76.3)$ & \\
\hline \multicolumn{4}{|l|}{ Difference in change pre to post } \\
\hline Proportion 3-5 (\% (95\% Cl)) & $21.0(13.3 ; 28.8)$ & $22.1(15.8 ; 28.5)$ & \\
\hline $\mathrm{p}$-value & $<0.00 \mathrm{I}^{\mathrm{a}}$ & $<0.00 \mathrm{I}^{\mathrm{a}}$ & $0.566^{\mathrm{b}}$ \\
\hline \multicolumn{4}{|l|}{ Children's rights } \\
\hline Pre, N & 221 & 454 & \\
\hline $3-5, \mathrm{n}(\%)$ & $122(55.2)$ & $296(65.2)$ & \\
\hline Post, $\mathrm{N}$ & 501 & 363 & \\
\hline $3-5, \mathrm{n}(\%)$ & $395(78.8)$ & $306(84.3)$ & \\
\hline \multicolumn{4}{|l|}{ Difference in change pre to post } \\
\hline Proportion 3-5 (\% (95\% Cl)) & $23.6(16.2 ; 31.1)$ & $19.1(13.3 ; 24.9)$ & \\
\hline $\mathrm{p}$-value & $<0.00 \mathrm{I}^{\mathrm{a}}$ & $<0.00 \mathrm{I}^{\mathrm{a}}$ & $0.827^{b}$ \\
\hline
\end{tabular}

Notes: ${ }^{\mathrm{a}} \mathrm{p}$-value for z-test for proportions; ${ }^{\mathrm{b}} \mathrm{p}$-value for logistic regression model.

Abbreviations: Pre, questionnaire data before course delivery; Post, questionnaire data after course delivery.

included in 2019), insight into children in general was significantly reduced from pre-course to post-course.

Insight into vulnerable/at-risk children in particular (Table 6) increased significantly from pre-course to postcourse among students in Physiotherapy (both $\mathrm{p}<0.001$ ), Mensendieck Physiotherapy (both $\mathrm{p}<0.001$ ), Teacher Education ( $p=0.001$ in 2019 and $p<0.001$ in 2020), and Early Childhood Education ( $\mathrm{p}=0.004$ in 2020 but not in 2019). Among students in Child Welfare, this insight decreased significantly in $2020(\mathrm{p}=0.02)$ and did not change in 2019.

Moreover, insight into children's rights increased significantly among students in Physiotherapy (both $\mathrm{p}<0.001$ ), Mensendieck Physiotherapy (both $\mathrm{p}<0.001$ ), Teacher Education ( $p<0.001$ in 2019 but not in 2020), Occupational Therapy $(p<0.001$ in 2019 and $p=0.002$ in 2020), and Teacher Education in Art and Design ( $\mathrm{p}=0.007$ in 2020). However, this insight decreased among students in Early Childhood Education in 2019 ( $\mathrm{p}=0.035)$ (Table 7).
The difference in the increase in insight into children in general and vulnerable/at-risk children from pre- to postcourse between 2019 and 2020 was significant among Physiotherapy students $(\mathrm{p}=0.030$ and $\mathrm{p}=0.049$, respectively) and Early Childhood Education students ( $\mathrm{p}=0.037$ and $p=0.002$, respectively) but not for the other groups (Tables 5-6). The reduction in insight into children's rights from pre- to post-course was significantly larger in 2019 than in 2020 among Early Childhood Education students $(p=0.037)$ but not in the other groups (Table 7).

\section{Variation in Student Responses According to Age}

In both age categories (below and above 25 years), students gained new academic insight into vulnerable/at-risk children and children's rights (all $\mathrm{p}<0.01$ in 2019 and 2020). Regarding insight into children in general, there 
Table 4 Differences Between 2019 and 2020 in Change from Pre-Course to Post-Course in Proportion of Agreeing Students (Score 3-5) Regarding "Children in General", "Vulnerable/At-Risk Children" and "Children's Rights", Stratified by Dichotomized Study Program

\begin{tabular}{|c|c|c|c|}
\hline & 2019 & 2020 & 2019 vs 2020 \\
\hline \multicolumn{4}{|l|}{ Children in general } \\
\hline \multicolumn{4}{|l|}{ Health and social care ${ }^{a}$} \\
\hline Pre, $N$ & 125 & 199 & \\
\hline $3-5, \mathrm{n}(\%)$ & $49(39.2)$ & $90(45.2)$ & \\
\hline Post, $\mathrm{N}$ & 243 & 167 & \\
\hline $3-5, \mathrm{n}(\%)$ & I74 (7I.6) & $133(79.6)$ & \\
\hline \multicolumn{4}{|l|}{ Difference in change pre to post } \\
\hline Proportion 3-5 (\% (95\% Cl)) & $32.4(22.1 ; 42.7)$ & $34.4(25.2 ; 43.6)$ & \\
\hline $\mathrm{p}$-value & $<0.00 \mathrm{I}^{\mathrm{b}}$ & $<0.00 \mathrm{I}^{\mathrm{b}}$ & $0.565^{\mathrm{c}}$ \\
\hline \multicolumn{4}{|c|}{ Teacher education and child welfare } \\
\hline Pre, $\mathrm{N}$ & 95 & 255 & \\
\hline $3-5, \mathrm{n}(\%)$ & $87(91.6)$ & $237(92.9)$ & \\
\hline Post, $N$ & 262 & 196 & \\
\hline $3-5, \mathrm{n}(\%)$ & $182(69.5)$ & $167(85.2)$ & \\
\hline \multicolumn{4}{|l|}{ Difference in change pre to post } \\
\hline Proportion 3-5 (\% (95\% Cl)) & $-22.1(-30.0 ;-14.2)$ & $-7.7(-13.6 ;-1.9)$ & \\
\hline $\mathrm{p}$-value & $<0.00 \mathrm{I}^{\mathrm{b}}$ & $0.008^{\mathrm{b}}$ & $0.144^{c}$ \\
\hline \multicolumn{4}{|l|}{ Vulnerable/at risk children } \\
\hline \multicolumn{4}{|l|}{ Health and social care ${ }^{a}$} \\
\hline Pre, $\mathrm{N}$ & 124 & 199 & \\
\hline $3-5, \mathrm{n}(\%)$ & $39(31.5)$ & $75(37.7)$ & \\
\hline Post, N & 243 & 167 & \\
\hline $3-5, \mathrm{n}(\%)$ & $160(65.8)$ & $119(71.3)$ & \\
\hline \multicolumn{4}{|l|}{ Difference in change pre to post } \\
\hline Proportion 3-5 (\% (95\% Cl)) & $34.3(24.3 ; 44.5)$ & $33.6(24.0 ; 43.2)$ & \\
\hline $\mathrm{p}$-value & $<0.00 \mathrm{I}^{\mathrm{b}}$ & $<0.00 \mathrm{I}^{\mathrm{b}}$ & $0.940^{c}$ \\
\hline \multicolumn{4}{|c|}{ Teacher education and child welfare } \\
\hline Pre, $\mathrm{N}$ & 96 & 255 & \\
\hline $3-5, n(\%)$ & $63(65.6)$ & $|7|(67.1)$ & \\
\hline Post, N & 260 & 196 & \\
\hline $3-5, \mathrm{n}(\%)$ & $179(68.8)$ & $158(80.6)$ & \\
\hline \multicolumn{4}{|l|}{ Difference in change pre to post } \\
\hline Proportion 3-5 (\% (95\% Cl)) & $3.2(-14.3 ; 7.8)$ & I $3.5(5.6 ; 2 \mid .5)$ & \\
\hline p-value & $0.562^{\mathrm{b}}$ & $0.001^{b}$ & $0.093^{c}$ \\
\hline \multicolumn{4}{|l|}{ Children's rights } \\
\hline \multicolumn{4}{|l|}{ Health and social care ${ }^{3}$} \\
\hline Pre, $\mathrm{N}$ & 125 & 199 & \\
\hline $3-5, \mathrm{n}(\%)$ & $50(40.0)$ & 89 (44.7) & \\
\hline Post, N & 243 & 167 & \\
\hline $3-5, \mathrm{n}(\%)$ & I89 (77.8) & $136(8 \mid .4)$ & \\
\hline
\end{tabular}


Table 4 (Continued).

\begin{tabular}{|c|c|c|c|}
\hline & 2019 & 2020 & 2019 vs 2020 \\
\hline \multicolumn{4}{|l|}{ Difference in change pre to post } \\
\hline Proportion 3-5 (\% (95\% Cl)) & $37.8(27.7 ; 47.8)$ & $36.7(27.6 ; 45.8)$ & \\
\hline $\mathrm{p}$-value & $<0.00 \mathrm{I}^{\mathrm{b}}$ & $<0.00 \mathrm{I}^{\mathrm{b}}$ & $0.925^{c}$ \\
\hline \multicolumn{4}{|c|}{ Teacher education and child welfare } \\
\hline Pre, $N$ & 96 & 255 & \\
\hline $3-5, \mathrm{n}(\%)$ & $72(75.0)$ & $207(8 \mathrm{I} .2)$ & \\
\hline Post, N & 258 & 196 & \\
\hline $3-5, n(\%)$ & $206(79.8)$ & $170(86.7)$ & \\
\hline \multicolumn{4}{|l|}{ Difference in change pre to post } \\
\hline Proportion 3-5 (\% (95\% Cl)) & $4.8(-5.1 ; \mid 4.8)$ & $5.5(-1.2 ; 12.3)$ & \\
\hline $\mathrm{p}$-value & $0.322^{\mathrm{b}}$ & $0.114^{\mathrm{b}}$ & $0.72 I^{c}$ \\
\hline
\end{tabular}

Notes: ${ }^{\mathrm{a}} \mathrm{p}$-value for z-test for proportions; ${ }^{\mathrm{b}} \mathrm{p}$-value for logistic regression model; conly Social Workers.

Abbreviations: Pre, questionnaire data before course delivery; Post, questionnaire data after course delivery.

were significant increases among students $<25$ years in $2020(\mathrm{p}=0.003)$ and among older students in 2019 $(\mathrm{p}=0.041)$ (data not shown).

\section{Sensitivity Analysis}

The results of sensitivity analyses assessing scores as continuous variables did not deviate from the analysis on dichotomized answer alternatives.

\section{Supervisors}

The supervisors mainly agreed that the students had gained deeper academic insight into children in general, vulnerable/at-risk children, and children's rights: none of the supervisors chose scores $0-2$, and all responses were evenly distributed between scores 3-5.

\section{Discussion}

The results of this study showed that the students wanted to learn more about child-related topics regardless of educational background and age and that most students possessed increased insight into these topics after the IPL course. Few students had learned about vulnerable/at-risk children as part of their training. After the IPL course, the students in health and social care generally felt that they had learned more than did the students in teacher education and child welfare; notably, the teacher education and child welfare students gained increased insight into vulnerable/at-risk children.

The present study corresponds with previous disciplinary research indicating that teachers, healthcare providers, and social care providers ${ }^{1,43-47,49,50}$ receive little or no training in recognizing and responding to child-related topics relevant to IPC targeting children, young people, and their families as end users. In particular, our data correlate with data from the study conducted by the Norwegian Centre for Violence and Traumatic Stress Studies in which students in teacher education and child welfare study programs were asked about the focus their program placed, if any, on the following topics: 1) The United Nations Convention on the Rights of the Child, 2) physical child abuse, 3) child sexual abuse, and 4) conversational methods with children. ${ }^{48}$ The study found a lack of educational preparation regarding how to deal with child maltreatment and no clear increase in focus on these issues in uniprofessional education programs in the period 2007-2015. ${ }^{48}$ This present study expands previous research by suggesting a serious gap between, on one hand, the intention in legislation and the United Nations Convention on the Rights of the Child ${ }^{31,51,72,73}$ and, on the other hand, implementation in educational programs, not only in teacher education and child welfare programs but also in health and social care programs.

Although the United Nations Convention on the Rights of the Child ${ }^{3}$ and the new law ${ }^{51}$ should guide teaching in professional study programs, implementation may, to some extent, vary. Teaching practices pertaining to various forms of child maltreatment are most likely influenced by factors such as cultural taboos and the personal characteristics of individual teachers. ${ }^{45,46}$ As such, there appears to be too much room for individual interpretation in the field of, for example, sexual abuse. ${ }^{46}$ 
Table 5 Differences Between 2019 and 2020 in Change from Pre-Course to Post-Course in Proportion of Agreeing Students (Score 3-5) Regarding “Children in General”, Stratified by Study Program

\begin{tabular}{|c|c|c|c|}
\hline & 2019 & 2020 & 2019 vs 2020 \\
\hline \multicolumn{4}{|l|}{ Nursing } \\
\hline Pre, $\mathrm{N}$ & 25 & 47 & \\
\hline $3-5$, n (\%) & $15(60.0)$ & $34(72.3)$ & \\
\hline Post, $\mathrm{N}$ & 49 & 35 & \\
\hline $3-5, \mathrm{n}(\%)$ & $30(61.2)$ & $21(60.0)$ & \\
\hline \multicolumn{4}{|l|}{ Difference in change pre to post } \\
\hline Proportion 3-5 (\% (95\% Cl)) & $1.2(-22.3 ; 26.1)$ & $-12.3(-33.6 ; 9.5)$ & \\
\hline $\mathrm{p}$-value & $0.920^{\mathrm{a}}$ & $0.238^{\mathrm{a}}$ & $0.380^{\mathrm{b}}$ \\
\hline \multicolumn{4}{|l|}{ Physiotherapy } \\
\hline Pre, $\mathrm{N}$ & 39 & 51 & \\
\hline $3-5, \mathrm{n}(\%)$ & $9(23.1)$ & II (2I.6) & \\
\hline Post, N & 104 & 29 & \\
\hline $3-5$, n (\%) & $74(7 I .2)$ & $28(96.6)$ & \\
\hline \multicolumn{4}{|l|}{ Difference in change pre to post } \\
\hline Proportion 3-5 (\% (95\% Cl)) & $48.1(28.8 ; 62.1)$ & $75.0(5.35 ; 85.3)$ & \\
\hline $\mathrm{p}$-value & $<0.00 \mathrm{I}^{\mathrm{a}}$ & $<0.00 \mathrm{I}^{\mathrm{a}}$ & $0.030^{\mathrm{b}}$ \\
\hline \multicolumn{4}{|l|}{ Mensendieck Physiotherapy } \\
\hline Pre, $\mathrm{N}$ & 14 & 26 & \\
\hline $3-5, \mathrm{n}(\%)$ & $2(14.3)$ & $5(19.2)$ & \\
\hline Post, $N$ & 16 & 18 & \\
\hline $3-5$, n (\%) & $14(87.5)$ & $17(94.4)$ & \\
\hline \multicolumn{4}{|l|}{ Difference in change pre to post } \\
\hline Proportion 3-5 (\% (95\% Cl)) & $73.2(33.1 ; 88.9)$ & $75.2(43.6 ; 88.3)$ & \\
\hline $\mathrm{p}$-value & $<0.00 \mathrm{I}^{\mathrm{a}}$ & $<0.00 \mathrm{I}^{\mathrm{a}}$ & $0.735^{\mathrm{b}}$ \\
\hline \multicolumn{4}{|l|}{ Teacher Education } \\
\hline Pre, $\mathrm{N}$ & 45 & 108 & \\
\hline $3-5, \mathrm{n}(\%)$ & $40(88.9)$ & $101(93.5)$ & \\
\hline Post, $\mathrm{N}$ & 133 & 92 & \\
\hline $3-5, \mathrm{n}(\%)$ & $94(70.7)$ & $76(82.6)$ & \\
\hline \multicolumn{4}{|l|}{ Difference in change pre to post } \\
\hline Proportion 3-5 (\% (95\% Cl)) & $-18.2(-29.3 ;-2.6)$ & $-10.9(-21.2 ;-1.2)$ & \\
\hline $\mathrm{p}$-value & $0.014^{\mathrm{a}}$ & $0.016^{\mathrm{a}}$ & $0.899^{\mathrm{b}}$ \\
\hline \multicolumn{4}{|c|}{ Early Childhood Education and Care } \\
\hline Pre, $N$ & 32 & 87 & \\
\hline $3-5, \mathrm{n}(\%)$ & $31(96.9)$ & $81(93.1)$ & \\
\hline Post, $\mathrm{N}$ & 95 & 69 & \\
\hline $3-5, \mathrm{n}(\%)$ & $63(66.3)$ & $63(91.3)$ & \\
\hline \multicolumn{4}{|l|}{ Difference in change pre to post } \\
\hline Proportion 3-5 (\% (95\% Cl)) & $-30.6(-41.5 ;-13.1)$ & $-1.8(-12.5 ; 7.8)$ & \\
\hline $\mathrm{p}$-value & $0.00 I^{\mathrm{a}}$ & $0.674^{\mathrm{a}}$ & $0.037^{b}$ \\
\hline
\end{tabular}


Table 5 (Continued).

\begin{tabular}{|c|c|c|c|}
\hline & 2019 & 2020 & 2019 vs 2020 \\
\hline \multicolumn{4}{|l|}{ Occupational Therapy } \\
\hline Pre, $\mathrm{N}$ & 15 & 30 & \\
\hline $3-5, \mathrm{n}(\%)$ & $4(26.7)$ & $15(50.0)$ & \\
\hline Post, N & 26 & 16 & \\
\hline $3-5, \mathrm{n}(\%)$ & $17(65.4)$ & $12(75.0)$ & \\
\hline \multicolumn{4}{|l|}{ Difference in change pre to post } \\
\hline Proportion 3-5 (\% (95\% Cl)) & $38.7(3.3 ; 63.1)$ & $25.0(-8.1 ; 49.8)$ & \\
\hline $\mathrm{p}$-value & $0.017^{\mathrm{a}}$ & $0.101^{\mathrm{a}}$ & $0.579^{\mathrm{b}}$ \\
\hline \multicolumn{4}{|l|}{ Child Welfare } \\
\hline Pre, $\mathrm{N}$ & 18 & 32 & \\
\hline $3-5, \mathrm{n}(\%)$ & $16(88.9)$ & $30(93.8)$ & \\
\hline Post, N & 34 & 35 & \\
\hline $3-5, \mathrm{n}(\%)$ & $25(73.5)$ & $28(80.0)$ & \\
\hline \multicolumn{4}{|l|}{ Difference in change pre to post } \\
\hline Proportion 3-5 (\% (95\% Cl)) & $-15.4(-35.7 ; 12.8)$ & $-13.8(-32.0 ; 5.6)$ & \\
\hline p-value & $0.197^{\mathrm{a}}$ & $0.099^{\mathrm{a}}$ & $0.825^{b}$ \\
\hline \multicolumn{4}{|l|}{ Social Work } \\
\hline Pre, $\mathrm{N}$ & 31 & 45 & \\
\hline $3-5$, n (\%) & $18(58.1)$ & $25(55.6)$ & \\
\hline Post, N & 46 & 46 & \\
\hline $3-5, \mathrm{n}(\%)$ & $39(84.8)$ & $32(69.6)$ & \\
\hline \multicolumn{4}{|l|}{ Difference in change pre to post } \\
\hline Proportion 3-5 (\% (95\% Cl)) & $26.7(4.6 ; 47.3)$ & $14.0(-7.2 ; 33.7)$ & \\
\hline $\mathrm{P}$-value & $0.009^{\mathrm{a}}$ & $0.168^{\mathrm{a}}$ & $0.262^{b}$ \\
\hline \multicolumn{4}{|c|}{ Teacher Education in Art and Design } \\
\hline Pre, N & & 28 & \\
\hline $3-5, \mathrm{n}(\%)$ & NA & $25(89.3)$ & \\
\hline Post, N & & 23 & \\
\hline $3-5$, n (\%) & & $23(100)$ & \\
\hline \multicolumn{4}{|l|}{ Difference in change pre to post } \\
\hline Proportion 3-5 (\% (95\% Cl)) & NA & $-7.7(-13.6 ;-1.9)$ & NA \\
\hline $\mathrm{p}$-value & & $0.008^{\mathrm{a}}$ & \\
\hline
\end{tabular}

Notes: ${ }^{a} \mathrm{p}$-value for z-test for proportions. ${ }^{\mathrm{b}} \mathrm{p}$-value for logistic regression model. Bold figures indicate a $\mathrm{p}$-value below 0.05 (considered statistically significant). Abbreviations: Pre, questionnaire data before course delivery; Post, questionnaire data after course delivery.

A more robust knowledge base on children and children's rights among the teacher education and child welfare students was to be expected. Thus, their lower learning outcomes from the IPL course on the topics dealing with normal and healthy childhood were also to be expected. Children who need help must receive it as early as possible to prevent their challenges from becoming greater and more complex. ${ }^{73}$ Teachers therefore play a vital role in identifying, reporting, and preventing various forms of child maltreatment. ${ }^{37,43}$ Although a positive relationship with a supportive adult, such as a teacher, can promote resilience in children who are victims of abuse, ${ }^{74}$ the present data suggest that teachers still lack relevant training. ${ }^{1,37-48}$ It was recently decided that, in Norwegian teacher education programs, priority should be given to three interdisciplinary themes: democracy and citizenship, sustainable development, and public health and well-being. ${ }^{75}$ Addressing child maltreatment 
Table 6 Differences Between 2019 and 2020 in Change from Pre-Course to Post-Course in Proportion of Agreeing Students (Score 3-5) Regarding "Vulnerable/At-Risk Children”, Stratified by Study Program

\begin{tabular}{|c|c|c|c|}
\hline & 2019 & 2020 & 2019 vs 2020 \\
\hline \multicolumn{4}{|l|}{ Nursing } \\
\hline Pre, $\mathrm{N}$ & 25 & 47 & \\
\hline $3-5, \mathrm{n}(\%)$ & $12(48.0)$ & $27(57.4)$ & \\
\hline Post, $\mathrm{N}$ & 49 & 35 & \\
\hline $3-5, \mathrm{n}(\%)$ & $29(59.2)$ & $19(54.3)$ & \\
\hline \multicolumn{4}{|l|}{ Difference in change pre to post } \\
\hline Proportion 3-5 (\% (95\% Cl)) & II.2 (-14.0; 35.0) & $-3.2(-25.5 ; 19.3)$ & \\
\hline $\mathrm{p}$-value & $0.356^{\mathrm{a}}$ & $0.772^{\mathrm{a}}$ & $0.386^{\mathrm{b}}$ \\
\hline \multicolumn{4}{|l|}{ Physiotherapy } \\
\hline Pre, $\mathrm{N}$ & 38 & 51 & \\
\hline $3-5, \mathrm{n}(\%)$ & $5(13.2)$ & $8(15.7)$ & \\
\hline Post, N & 103 & 29 & \\
\hline $3-5, \mathrm{n}(\%)$ & $70(68.0)$ & $28(96.6)$ & \\
\hline \multicolumn{4}{|l|}{ Difference in change pre to post } \\
\hline Proportion 3-5 (\% (95\% Cl)) & $54.8(36.2 ; 66.7)$ & $80.1(59.8 ; 89.7)$ & \\
\hline $\mathrm{p}$-value & $<0.00 \mathrm{I}^{\mathrm{a}}$ & $<0.00 \mathrm{I}^{\mathrm{a}}$ & $0.049^{b}$ \\
\hline \multicolumn{4}{|l|}{ Mensendieck Physiotherapy } \\
\hline Pre, $\mathrm{N}$ & 14 & 26 & \\
\hline $3-5, \mathrm{n}(\%)$ & $2(14.3)$ & $2(7.7)$ & \\
\hline Post, N & 16 & 18 & \\
\hline $3-5, \mathrm{n}(\%)$ & $13(81.3)$ & $16(88.9)$ & \\
\hline \multicolumn{4}{|l|}{ Difference in change pre to post } \\
\hline Proportion 3-5 (\% (95\% Cl)) & $67.0(26.6 ; 85.1)$ & $81.2(49.9 ; 92.3)$ & \\
\hline p-value & $<0.001^{\mathrm{a}}$ & $<0.001^{\mathrm{a}}$ & $0.367^{b}$ \\
\hline \multicolumn{4}{|l|}{ Teacher Education } \\
\hline Pre, $\mathrm{N}$ & 45 & 108 & \\
\hline $3-5, \mathrm{n}(\%)$ & $21(46.7)$ & $62(57.4)$ & \\
\hline Post, $N$ & 133 & 92 & \\
\hline $3-5, \mathrm{n}(\%)$ & $98(73.7)$ & $75(81.5)$ & \\
\hline \multicolumn{4}{|l|}{ Difference in change pre to post } \\
\hline Proportion 3-5 (\% (95\% Cl)) & $27.0(9.5 ; 43.4)$ & $24.1(10.6 ; 36.3)$ & \\
\hline p-value & $0.00 I^{\mathrm{a}}$ & $<0.001^{\mathrm{a}}$ & $0.963^{b}$ \\
\hline \multicolumn{4}{|c|}{ Early Childhood Education and Care } \\
\hline Pre, $\mathrm{N}$ & 33 & 87 & \\
\hline $3-5, \mathrm{n}(\%)$ & $25(75.8)$ & $60(69.0)$ & \\
\hline Post, N & 93 & 69 & \\
\hline $3-5, \mathrm{n}(\%)$ & $56(60.2)$ & $61(88.4)$ & \\
\hline \multicolumn{4}{|l|}{ Difference in change pre to post } \\
\hline Proportion 3-5 (\% (95\% Cl)) & $-15.5(-32.0 ; 5.3)$ & $19.4(5.4 ; 32.0)$ & \\
\hline $\mathrm{p}$-value & $0.110^{\mathrm{a}}$ & $0.004^{\mathrm{a}}$ & $0.002^{b}$ \\
\hline
\end{tabular}


Table 6 (Continued).

\begin{tabular}{|c|c|c|c|}
\hline & 2019 & 2020 & 2019 vs 2020 \\
\hline \multicolumn{4}{|l|}{ Occupational Therapy } \\
\hline Pre, $\mathrm{N}$ & 15 & 30 & \\
\hline $3-5, \mathrm{n}(\%)$ & $3(20.0)$ & $14(46.7)$ & \\
\hline Post, N & 26 & 16 & \\
\hline $3-5, \mathrm{n}(\%)$ & $13(50.0)$ & $7(43.8)$ & \\
\hline \multicolumn{4}{|l|}{ Difference in change pre to post } \\
\hline Proportion 3-5 (\% (95\% Cl)) & $30.0(-4.7 ; 54.5)$ & $-2.9(-32.6 ; 28.4)$ & \\
\hline $\mathrm{p}$-value & $0.057^{\mathrm{a}}$ & $0.849^{\mathrm{a}}$ & $0.124^{b}$ \\
\hline \multicolumn{4}{|l|}{ Child Welfare } \\
\hline Pre, $\mathrm{N}$ & 18 & 32 & \\
\hline $3-5, \mathrm{n}(\%)$ & $17(94.4)$ & $28(87.5)$ & \\
\hline Post, N & 34 & 35 & \\
\hline $3-5, \mathrm{n}(\%)$ & $25(73.5)$ & $22(62.9)$ & \\
\hline \multicolumn{4}{|l|}{ Difference in change pre to post } \\
\hline Proportion 3-5 (\% (95\% Cl)) & $-20.9(-39.8 ; 6.2)$ & $-24.6(-44.4 ;-1.6)$ & \\
\hline $\mathrm{p}$-value & $0.069^{\mathrm{a}}$ & $0.020^{\mathrm{a}}$ & $0.758^{\mathrm{b}}$ \\
\hline \multicolumn{4}{|l|}{ Social Work } \\
\hline Pre, $\mathrm{N}$ & 31 & 45 & \\
\hline $3-5$, n (\%) & $16(51.6)$ & $24(53.3)$ & \\
\hline Post, N & 47 & 46 & \\
\hline $3-5, \mathrm{n}(\%)$ & $34(72.3)$ & $28(60.9)$ & \\
\hline \multicolumn{4}{|l|}{ Difference in change pre to post } \\
\hline Proportion 3-5 (\% (95\% Cl)) & $20.7(-2.7 ; 42.3)$ & $7.5(-13.8 ; 28.1)$ & \\
\hline $\mathrm{P}$-value & $0.061^{\mathrm{a}}$ & $0.465^{\mathrm{a}}$ & $0.362^{b}$ \\
\hline \multicolumn{4}{|c|}{ Teacher Education in Art and Design } \\
\hline Pre, N & & 28 & \\
\hline $3-5, \mathrm{n}(\%)$ & NA & $21(75.0)$ & \\
\hline Post, N & & 23 & \\
\hline $3-5$, n (\%) & & $21(91.3)$ & \\
\hline \multicolumn{4}{|l|}{ Difference in change pre to post } \\
\hline Proportion 3-5 (\% (95\% Cl)) & NA & $16.3(-8.5 ; 37.8)$ & NA \\
\hline p-value & & $0.129^{\mathrm{a}}$ & \\
\hline
\end{tabular}

Notes: ${ }^{\mathrm{a}} \mathrm{p}$-value for z-test for proportions. ${ }^{\mathrm{b}} \mathrm{p}$-value for logistic regression model. Bold figures indicate a $\mathrm{p}$-value below 0.05 (considered statistically significant). Abbreviations: Pre, questionnaire data before course delivery; Post, questionnaire data after course delivery.

and abnormal childhood experiences could form part of these interdisciplinary themes. ${ }^{46}$

Student-led discussions around video-based cases $^{65,76,77}$ guided the IPL group work (case-based learning). The IPL groups were, however, free to discuss and add any IPC-relevant issues in their IPL group discussions, in addition to the predefined tasks, based on, for example, their previous work experience or uniprofessional training and/or theoretical knowledge. The essence of IPL is for students to learn with, from, and about other professions. ${ }^{52}$ It is therefore possible that some of the IPL groups discussed the NICE (National Institute for Health \& Care Excellence) guidelines, ${ }^{78}$ which aim to raise awareness and assist professionals who are not child protection specialists in talking with children and identifying the features of physical, sexual, and emotional abuse, neglect, and fabricated or induced illness. It is also possible that some of the IPL groups discussed use of ACE (Adverse 
Table 7 Differences Between 2019 and 2020 in Change from Pre-Course to Post-Course in Proportion of Agreeing Students (Score 3-5) Regarding “Children's Right”, Stratified by Study Program

\begin{tabular}{|c|c|c|c|}
\hline & 2019 & 2020 & 2019 vs 2020 \\
\hline \multicolumn{4}{|l|}{ Nursing } \\
\hline Pre, $\mathrm{N}$ & 25 & 47 & \\
\hline $3-5, \mathrm{n}(\%)$ & $14(56.0)$ & $22(46.8)$ & \\
\hline Post, N & 48 & 35 & \\
\hline $3-5, \mathrm{n}(\%)$ & $37(77.1)$ & $22(62.9)$ & \\
\hline \multicolumn{4}{|l|}{ Difference in change pre to post } \\
\hline Proportion 3-5 (\% (95\% Cl)) & $21.1(-3.0 ; 44.3)$ & I6.I $(-7.3 ; 37.0)$ & \\
\hline p-value & $0.063^{\mathrm{a}}$ & $0.150^{\mathrm{a}}$ & $0.649^{b}$ \\
\hline \multicolumn{4}{|l|}{ Physiotherapy } \\
\hline Pre, $N$ & 39 & 51 & \\
\hline $3-5, \mathrm{n}(\%)$ & $6(15.4)$ & $20(39.2)$ & \\
\hline Post, N & 104 & 29 & \\
\hline $3-5, \mathrm{n}(\%)$ & $82(78.8)$ & $28(96.6)$ & \\
\hline \multicolumn{4}{|l|}{ Difference in change pre to post } \\
\hline Proportion 3-5 (\% (95\% Cl)) & $63.5(45.1 ; 74.9)$ & $57.3(35.5 ; 70.8)$ & \\
\hline $\mathrm{p}$-value & $<0.00 \mathrm{I}^{\mathrm{a}}$ & $<0.00 \mathrm{I}^{\mathrm{a}}$ & $0.522^{b}$ \\
\hline \multicolumn{4}{|l|}{ Mensendieck Physiotherapy } \\
\hline Pre, $\mathrm{N}$ & 14 & 26 & \\
\hline $3-5, \mathrm{n}(\%)$ & $2(14.3)$ & $2(7.7)$ & \\
\hline Post, N & 16 & 18 & \\
\hline $3-5, \mathrm{n}(\%)$ & $15(93.8)$ & $17(94.4)$ & \\
\hline \multicolumn{4}{|l|}{ Difference in change pre to post } \\
\hline Proportion 3-5 (\% (95\% Cl)) & 79.5 (40.I; 92.6) & $86.8(56.3 ; 95.0)$ & \\
\hline p-value & $<0.001^{\mathrm{a}}$ & $<0.001^{\mathrm{a}}$ & $0.650^{\mathrm{b}}$ \\
\hline \multicolumn{4}{|l|}{ Teacher Education } \\
\hline Pre, $\mathrm{N}$ & 45 & 108 & \\
\hline $3-5, \mathrm{n}(\%)$ & $25(55.6)$ & $82(75.9)$ & \\
\hline Post, $N$ & $|3|$ & 92 & \\
\hline $3-5, \mathrm{n}(\%)$ & $113(86.3)$ & $79(85.9)$ & \\
\hline \multicolumn{4}{|l|}{ Difference in change pre to post } \\
\hline Proportion 3-5 (\% (95\% Cl)) & $30.7(14.4 ; 47.0)$ & $9.9(-1.9 ; 21.1)$ & \\
\hline $\mathrm{p}$-value & $<0.00 \mathrm{I}^{\mathrm{a}}$ & $0.077^{\mathrm{b}}$ & $0.078^{\mathrm{b}}$ \\
\hline \multicolumn{4}{|c|}{ Early Childhood Education and Care } \\
\hline Pre, $\mathrm{N}$ & 33 & 87 & \\
\hline $3-5, \mathrm{n}(\%)$ & $30(90.9)$ & $77(88.5)$ & \\
\hline Post, N & 93 & 69 & \\
\hline $3-5, \mathrm{n}(\%)$ & $68(73.1)$ & $64(92.8)$ & \\
\hline \multicolumn{4}{|l|}{ Difference in change pre to post } \\
\hline Proportion 3-5 (\% (95\% Cl)) & $-17.8(-29.3 ;-1.3)$ & $4.3(-6.8 ; 14.4)$ & \\
\hline $\mathrm{p}$-value & $0.035^{\mathrm{a}}$ & $0.373^{\mathrm{a}}$ & $0.037^{\mathrm{b}}$ \\
\hline
\end{tabular}

(Continued) 
Table 7 (Continued).

\begin{tabular}{|c|c|c|c|}
\hline & 2019 & 2020 & 2019 vs 2020 \\
\hline \multicolumn{4}{|l|}{ Occupational Therapy } \\
\hline Pre, $\mathrm{N}$ & 15 & 30 & \\
\hline $3-5, \mathrm{n}(\%)$ & $2(13.3)$ & $12(40.0)$ & \\
\hline Post, N & 26 & 16 & \\
\hline $3-5, \mathrm{n}(\%)$ & $19(73.1)$ & 14 (87.5) & \\
\hline \multicolumn{4}{|l|}{ Difference in change pre to post } \\
\hline Proportion 3-5 (\% (95\% Cl)) & $59.7(24.4 ; 78.0)$ & $47.5(14.3 ; 67.2)$ & \\
\hline $\mathrm{p}$-value & $<0.00 \mathrm{I}^{\mathrm{a}}$ & $0.002^{\mathrm{a}}$ & $0.670^{\mathrm{b}}$ \\
\hline \multicolumn{4}{|l|}{ Child Welfare } \\
\hline Pre, $\mathrm{N}$ & 18 & 32 & \\
\hline $3-5, \mathrm{n}(\%)$ & $17(94.4)$ & $30(93.8)$ & \\
\hline Post, N & 34 & 35 & \\
\hline $3-5, \mathrm{n}(\%)$ & $25(73.5)$ & $27(77.1)$ & \\
\hline \multicolumn{4}{|l|}{ Difference in change pre to post } \\
\hline Proportion 3-5 (\% (95\% Cl)) & $-20.9(-39.8 ; 6.2)$ & $-16.6(-35.0 ; 3.3)$ & \\
\hline p-value & $0.069^{\mathrm{a}}$ & $0.056^{\mathrm{a}}$ & $0.817^{b}$ \\
\hline \multicolumn{4}{|l|}{ Social Work } \\
\hline Pre, $\mathrm{N}$ & 31 & 47 & \\
\hline $3-5, \mathrm{n}(\%)$ & $26(83.9)$ & $35(74.5)$ & \\
\hline Post, N & 47 & 45 & \\
\hline $3-5, \mathrm{n}(\%)$ & $35(74.5)$ & $33(73.3)$ & \\
\hline \multicolumn{4}{|l|}{ Difference in change pre to post } \\
\hline Proportion 3-5 (\% (95\% Cl)) & $-9.4(-27.5 ; 12.0)$ & $-1.1(-20.2 ; 17.9)$ & \\
\hline $\mathrm{P}$-value & $0.327^{\mathrm{a}}$ & $0.904^{\mathrm{a}}$ & $0.510^{\mathrm{b}}$ \\
\hline \multicolumn{4}{|c|}{ Teacher Education in Art and Design } \\
\hline Pre, N & & 28 & \\
\hline $3-5, \mathrm{n}(\%)$ & NA & $18(64.3)$ & \\
\hline Post, N & & 23 & \\
\hline $3-5$, n (\%) & & $22(95.7)$ & \\
\hline \multicolumn{4}{|l|}{ Difference in change pre to post } \\
\hline Proportion 3-5 (\% (95\% Cl)) & NA & $31.4(5.8 ; 52.0)$ & NA \\
\hline $\mathrm{p}$-value & & $0.007^{\mathrm{a}}$ & \\
\hline
\end{tabular}

Notes: ${ }^{\mathrm{a}} \mathrm{p}$-value for z-test for proportions. ${ }^{\mathrm{b}} \mathrm{p}$-value for logistic regression model. Bold figures indicate a $\mathrm{p}$-value below 0.05 (considered statistically significant). Abbreviations: Pre, questionnaire data before course delivery; Post, questionnaire data after course delivery.

Childhood Experiences) scores, ${ }^{8,25}$ which describe the relationship between ACEs, disease, and potential early death. $^{25,74}$ Moreover, some of the students might have been aware of the existence of digital avatars aimed at training professionals to talk to children about neglect, sexual abuse, and violence, the purpose of which is to improve the skills of professionals or adults tasked with protecting vulnerable/at-risk children. ${ }^{79,80}$ When using these avatars, learners may roleplay as various adults and practice interacting with children who may have been subjected to abuse, violence, or other forms of neglect. The aim is to train the learners to build trust with children through conversation. They also learn what they should do in practice if they ever find themselves in a situation in which a child shares something that requires them to put the child in contact with other public bodies. Such tools may be used in both uniprofessional and IPL courses. 
It is a complex task to develop learning designs on child-related topics, including child maltreatment, that give high learning outcomes for students from many different education programs. Nevertheless, we assume that these students' interprofessional networks were most probably expanded due to the compulsory two-day group assignment with peers from other education programs and to interaction with supervisors. Feedback, which is important for learning outcomes, ${ }^{81}$ was provided by the supervisors, who also answered any questions from the IPL groups. The supervisors' responses corresponded with the students' responses with respect to the importance of aligning curricula with both legislation on child maltreatment ${ }^{29-32}$ and with the parts of the United Nations Convention on the Rights of the Child that go beyond normal and healthy childhood experiences. $^{3,12}$ Although the sample size of supervisor responses is too small to draw any reliable conclusions, the correspondence is interesting, as most supervisors were not educated as health personnel. ${ }^{54}$

The IPL course is intended for first-year students. We cannot exclude the possibility that the uniprofessional education programs provided lectures dealing with child-related topics, including various forms of maltreatment, later on in the programs. However, we find this unlikely based on the documented failure in services and on previous research. $^{45,46,48,50}$ Moreover, the similarity between the responses from the second-year and first-year students indicates a lack of further uniprofessional training for secondyear students.

This project does not involve patients or clients and is solely a face-to-face IPL pre-service training course that was provided on campus. Data from 32 institutions in Norway has shown that nursing and medical educations, in 2011, educated their students theoretically about IPC. ${ }^{82}$ Although three of the four medical programs included in this study had integrated IPC into their clinical training, there was a gap in the nursing programs, where the introduction of IPC in clinical training was limited. ${ }^{82}$ In the 2020/2021 academic year, all health and social care education programs in Norway were obliged to implement IPL in undergraduate studies, and several common learning outcomes were formulated. ${ }^{83}$ In the future, all professional students at OsloMet will complete the IPL course once each year of their three-year bachelor education (total 4.5 ECTS) ${ }^{61}$ However, the common learning outcomes pertaining to children, young people, and their families ${ }^{83}$ make no explicit mention of various forms of child maltreatment. If local educators have the opportunity to choose whether or not to include child maltreatment in curricula, important topics may be omitted. ${ }^{45,46}$ Given that child maltreatment causes suffering to children and families and can have longterm health consequences, ${ }^{10,12,26,78,84}$ education on maltreatment cannot be omitted from professional programs and must be mentioned explicitly in the curricula.

The need for professional training in child-related topics was highlighted during the COVID-19 pandemic restrictions and will continue to be relevant afterwards. ${ }^{49,85-87}$ Some children experienced a higher burden due to the pandemic than other children, and with a high risk of violation of their rights. ${ }^{86}$ It has been suggested that case detection and reporting has decreased as a consequence of pandemic measures, ${ }^{85}$ leading to an underestimation of the prevalence of various forms of child maltreatment. The present data were collected preand post-course delivery in 2019 and 2020 (ie only a few weeks before the lockdown due to the COVID-19 pandemic in Norway). Although it may become more difficult to collect data after the lockdown, that challenge is beyond the scope of the present pre-pandemic study.

Children need safe, stable, nurturing environments that foster their healthy growth and development. ${ }^{14}$ The curricula and the textbooks must be updated, and relevant preservice training must be offered to students. Professionals have requested experience, counseling, knowledge, training, and guidelines to more efficiently address these issues. ${ }^{88}$ The Norwegian government has published an action plan entitled A Good Childhood Lasts a Lifetime that includes a stronger focus on violence and child sexual abuse in professional education programs. ${ }^{89}$ Without increased awareness and adequate training for future teachers and for health and social care workers, child maltreatment will continue to go undetected. ${ }^{35,49}$

\section{Limitations and Strengths}

Admittedly, self-selection bias cannot be excluded; however, the diversity in our sample enhances the robustness of the findings. Though the relatively low response rate, which was in line with a declining response rate for surveys in general, might threaten the validity and generalizability of the results, a high response rate does not guarantee sample quality. ${ }^{90,91}$ Using data from two consecutive course deliveries in 2019 and 2020 and from a large heterogeneous sample of students with different educational backgrounds should partially compensate for possible selection bias. The students' responses were stable between 2019 and 2020, implying stability along 
the time axis. This is a major strength of the present study. Moreover, the anonymous data collection, the large heterogeneous sample size of students, and the varying educational backgrounds of the participants also strengthen the study. The fact that the teacher education students initially reported a more expansive knowledge base about children's rights and children in general lends credibility to our results. Although the number of responding supervisors was only 13 (response rate 39.1\%), the supervisors response was similar to that of students. The similarity in the responses from the second-year and first-year students also indicates a lack of uniprofessional training for the second-year students in child-related topics, including various forms of child maltreatment. Although this study's cross-sectional design does not allow for the assessment of causality, these findings should be further explored in future studies. Future studies might also investigate the content in professional curricula in higher education, for example, a manifest content analysis. ${ }^{92}$ Complementary content analysis results would further strengthen the conclusion of this study. To further prepare the different student groups ahead of IPL targeting children-related topics, future research could also be qualitative and might pursue an in-depth understanding of how educators may counteract the knowledge boundaries between different professions (such as differences in legislation and duties of confidentiality as well as between different definitions, cultures, curricula, procedures, and knowledge bases). ${ }^{51}$ OsloMet is one of Norway's largest universities and is home to some of Norway's oldest, largest, and bestknown programs of professional study. As professional curricula content is regulated by the Norwegian government, this study can be applied to other types of health care, social, and teachers educations in Norway. Moreover, since maltreatment of children is not an isolated Norwegian phenomenon, findings could be of interest to professional educators also outside Norway.

\section{Conclusion}

Most of the students who participated in this study wanted to gain more insight into child-related topics, and few of them had previously learned about vulnerable/at-risk children in their uniprofessional education programs. After the IPL course, the health and social care students generally reported that they learned more than the teacher education and child welfare students but, notably, the teacher education and child welfare students gained increased insight into vulnerable/at-risk children. Age was of minor importance. This study reveals a gap between the intention of the law and curricular content in health, social care, and teacher education programs. This study is applicable to other types of professional education in Norway. Further, this study's focus on all children in education could also facilitate modernization of health care, social, and teacher education curricula outside of Norway.

\section{Acknowledgments}

First and foremost, we wish to thank the participants. We also wish to thank the academic and administrative staff at Oslo Metropolitan University for their contributions to this work. A special thanks to Ellen Merethe Magnus, administrative manager, INTERACT and Torhild Skotheim, project manager, INTERACT.

\section{Disclosure}

The authors report no conflicts of interest in this work.

\section{References}

1. Baker AJL, LeBlanc S, Adebayo T, Mathews B. Training for mandated reporters of child abuse and neglect: content analysis of state-sponsored curricula. Child Abuse Negl. 2021;113:104932. doi:10.1016/j.chiabu.2021.104932

2. Wright RJ, Wright RO, Farnan L, Isaac NE. Response to child abuse in the pediatric emergency department: need for continued education. Pediatr Emerg Care. 1999;15(6):376-382. doi:10.1097/00006565199912000-00002

3. United Nations. Convention on the Rights of the Child. Available from: https://www.ohchr.org/en/professionalinterest/pages/crc.aspx. Accessed August 26, 2021.

4. Russell DH, Trew S, Higgins DJ. Vulnerable yet forgotten? A systematic review identifying the lack of evidence for effective suicide interventions for young people in contact with child protection systems. Am J Orthopsychiatry. 2021;91(5):647-659. doi:10.1037/ort0000555

5. Goemans A, Viding E, McCrory E. Child maltreatment, peer victimization, and mental health: neurocognitive perspectives on the cycle of victimization. Trauma Violence Abuse. 2021;15248380211036393. doi: $10.1177 / 15248380211036393$

6. Hafstad GS, Sætren SS, Myhre MC, Bergerud-Wichstrøm M, Augusti E-M. Cohort profile: Norwegian youth study on child maltreatment (the UEVO study). BMJ Open. 2020;10(8):e038655. doi:10.1136/bmjopen-2020-038655

7. United Nations Children's Fund UN. Violence prevention must start in early childhood. United Nations Children's Fund UN. Violence prevention must start in early childhood. Available from: https://violencea gainstchildren.un.org/news/violence-prevention-must-start-early-child hood. Accessed November 18, 2021.

8. Prevent Child Abuse America. Long term effects of child abuse and neglect. Available from: https://preventchildabuse.org/latest-activity/longterm-effects-of-child-abuse-and-neglect/? gclid= Cj0KCQjwrJOMBhCZARIsAGE\%20d4VF98r6mMGyHUy82DifOlGj_ AcQC5Fo1FjqFR61KDqLcg9tYM4LnKLYaAtUvEALw_wcB. Accessed November 18, 2021.

9. Haugland SH, Dovran A, Albaek AU, Sivertsen B. Adverse childhood experiences among 28,047 Norwegian adults from a general population. Front Public Health. 2021;9(1054). doi:10.3389/ fpubh.2021.711344 
10. Gilbert R, Widom CS, Browne K, Fergusson D, Webb E, Janson S. Burden and consequences of child maltreatment in high-income countries. Lancet. 2009;373(9657):68-81. doi:10.1016/s01406736(08)61706-7

11. Failure and betrayal: Review of cases where children have been exposed to violence,sexual abuse and neglect; 2017:12. Available from: https://www.regjeringen.no/contentassets/a44ef6e251c d443396588483e97402ab/no/pdfs/nou201720170012000dddpdfs.pdf. Accessed December 10, 2021.

12. World Health Organization. WHO guidelines for the health sector response to child maltreatment: technical report; 2019. Available from: https://www.who.int/publications/i/item/who-guidelines-for-the -health-sector-response-to-child-maltreatment. Accessed September $15,2021$.

13. Hafstad G, Augusti E. Childhood experiences of violence and abuse: a national survey of Norwegian adolescents 12 to 16 years of age; 2019. Available from: https://www.nkvts.no/english/report/child hood-experiences-of-violence-and-abuse-a-national-survey-ofnorwegian-adolescents-12-to-16-years-of-age/. Accessed September 23, 2021.

14. Arora SK, Shah D, Chaturvedi S, Gupta P. Defining and measuring vulnerability in young people. Indian J Community Med. 2015;40 (3):193-197. doi:10.4103/0970-0218.158868

15. World report on violence and health; 2002. Available from: http:// apps.who.int/iris/bitstream/handle/10665/42495/9241545615_eng. pdf;sequence=1. Accessed September 23, 2021.

16. Hsiao YJ. Parental stress in families of children with disabilities. Interv Sch Clin. 2018;53(4):201-205. doi:10.1177/1053451217712956

17. Gander T, Boonmann C, Fegert JM, et al. Predictive factors for changes in quality of life among children and adolescents in youth welfare institutions. Soc Psychiatry Psychiatr Epidemiol. 2019;54 (12):1575-1586. doi:10.1007/s00127-019-01724-8

18. Kallander EK. Children affected by parental illness or parental substance abuse: young carers, well-being and quality of life; 2019 Available from: file://C:/Users/kalmendi/Downloads/PhD-Kallander -2020.pdf. Accessed November 30, 2021.

19. Sharpe D, Rossiter L. Siblings of children with a chronic illness: a meta-analysis. J Pediatr Psychol. 2002;27(8):699-710. doi:10.1093/ jpepsy/27.8.699

20. Sands A, Thompson EJ, Gaysina D. Long-term influences of parental divorce on offspring affective disorders: a systematic review and meta-analysis. J Affect Disord. 2017;218:105-114. doi:10.1016/j. jad.2017.04.015

21. Purvis M. Paternal incarceration and parenting programs in prison: a review paper. Psychiatr Psychol Law. 2013;20(1):9-28. doi:10.1080/13218719.2011.615822

22. Rossow I, Felix L, Keating P, McCambridge J. Parental drinking and adverse outcomes in children: a scoping review of cohort studies. Drug Alcohol Rev. 2016;35(4):397-405. doi:10.1111/dar.12319

23. Odenbring Y. The daily life and reality behind child poverty in Sweden: children's and adolescents' voices. Child Indic Res. 2019;12(3):847-859. doi:10.1007/s12187-018-9558-z

24. Ministry of Children and Equality. The rights of the child in Norway. Norway's fifth and sixth periodic reports to the UN committee on the rights of the child; 2016. Available from: https://www.regjeringen.no/ contentassets/0ada3bee46b54f498707f51bbc7d4b2c/barnekonvensjo nen-engelsk-versjon-uu.pdf. Accessed November 30, 2021.

25. Felitti VJ, Anda RF, Nordenberg D, et al. Relationship of childhood abuse and household dysfunction to many of the leading causes of death in adults: the Adverse Childhood Experiences (ACE) study. $\mathrm{Am}$ $J$ Prev Med. 1998;14(4):245-258. doi:10.1016/S0749-3797(98) 00017-8

26. Stoltenborgh M, Bakermans-Kranenburg MJ, Alink LRA, van IJzendoorn $\mathrm{MH}$. The prevalence of child maltreatment across the globe: review of a series of meta-analyses. Child Abus Rev. 2015;24(1):37-50. doi:10.1002/car.2353
27. Kloppen K, Mæhle M, Ø K, Haugland S, Breivik K. Prevalence of intrafamilial child maltreatment in the Nordic countries: a review. Child Abus Rev. 2014;24. doi:10.1002/car.2324.

28. Statistics Norway. Child welfare services statistics. Available from: https://www.ssb.no/en/sosiale-forhold-og-kriminalitet /barne-og-familievern/statistikk/barnevern. Accessed November 30, 2021.

29. The health personnel act. Lovdata; 1999. Available from: https:// www.regjeringen.no/no/dokumenter/act-of-2-july-1999-no-64-relat ing-to-hea/id107079/. Accessed December 10, 2021.

30. Act relating to primary and secondary education and training; 1998. Available from: https://lovdata.no/dokument/NLE/lov/1998-07-1761. Accessed December 10, 2021.

31. The child welfare act; 1992. Available from: https://www.regjeringen. no/globalassets/upload/bld/lover/barnevernloven-engelsk-01-012010.pdf. Accessed December 10, 2021.

32. The social services act; 2009. Available from: https://www.regjerin gen.no/en/dokumenter/the-child-welfare-act/id448398/. Accessed December 10, 2021

33. Statens helsetilsyn. Norwegian Board of Health Supervision. Review of 106 child welfare cases; 2019. Available from: https://www.helse tilsynet.no/globalassets/opplastinger/publikasjoner/rapporter2019/hel setilsynet_rapport_unummerert_gjennomgang_106_barnevernsaker. pdf. Accessed November 30, 2021.

34. The voice of the child is not heard. Summary of countrywide supervision in 2017 of The Norwegian Directorate for Children, Youth and Family Affairs. The Norwegian Board of Health Supervision 3/2018. Available from: https://www.helsetilsynet.no/ globalassets/opplastinger/publikasjoner/rapporter2018/helsetilsyne trapport3_2018.pdf. Accessed September 01, 2021.

35. Alvarez KM, Kenny MC, Donohue B, Carpin KM. Why are professionals failing to initiate mandated reports of child maltreatment, and are there any empirically based training programs to assist professionals in the reporting process? Aggress Violent Behav. 2004;9 (5):563-578. doi:10.1016/j.avb.2003.07.001

36. Brattabø IV, Bjørknes R, Åstrøm AN. Reasons for reported suspicion of child maltreatment and responses from the child welfare a cross-sectional study of Norwegian public dental health personnel. BMC Oral Health. 2018;18(1):29. doi:10.1186/s12903018-0490-x

37. Crosson-Tower $\mathrm{C}$. The role of educators in preventing and responding to child abuse a nd neglect; 2003. Available from: https://www. childwelfare.gov/pubpdfs/educator.pdfhttps:/www.childwelfare.gov/ pubpdfs/educator.pdf. Accessed November 30, 2021.

38. Feng JY, Huang TY, Wang CJ. Kindergarten teachers' experience with reporting child abuse in Taiwan. Child Abuse Negl. 2010;34 (2):124-128. doi:10.1016/j.chiabu.2009.05.007

39. Kenny MC. Child abuse reporting: teachers' perceived deterrents. Child Abuse Negl. 2001;25(1):81-92. doi:10.1016/s0145-2134(00) 00218-0

40. McKee BE, Dillenburger K. Child abuse and neglect: training needs of student teachers. Int $J$ Educ Res. 2009;48(5):320-330. doi:10.1016/j.ijer.2010.03.002

41. Molnar A, Gliszczinski C. Child abuse: a curriculum issue in teacher education. $J$ Teach Educ. 1983;34(5):39-41. doi:10.1177/ 002248718303400511

42. Sinanan AN. Bridging the gap of teacher education about child abuse. Educ Found. 2011;25:59-73.

43. Walsh K, Bridgstock R, Farrell A, Rassafiani M, Schweitzer R. Case, teacher and school characteristics influencing teachers' detection and reporting of child physical abuse and neglect: results from an Australian survey. Child Abuse Negl. 2008;32(10):983-993. doi:10.1016/j.chiabu.2008.03.002

44. Alazri Z, Hanna KM. School personnel and child abuse and neglect reporting behavior: an integrative review. Child Youth Serv Rev. 2020;112:104892. doi:10.1016/j.childyouth.2020.104892 
45. Goldschmidt-Gjerløw B. Children's rights and teachers' responsibilities: reproducing or transforming the cultural taboo on child sexual abuse? Hum Rights Rev. 2019;2(1):25-46. doi:10.7577/ hrer.3079

46. Goldschmidt-Gjerløw B. Exploring variation in Norwegian social science teachers' practice concerning sexuality education: who teachers are matters and so does school culture. Scand J Educ Res. 2021;1-16. doi:10.1080/00313831.2020.1869072

47. Treacy M, Nohilly M. Teacher education and child protection: complying with requirements or putting children first? Child Youth Serv Rev. 2020;113:105009. doi:10.1016/j.childyouth.2020. 105009

48. Øverlien C, Moen LH. Takk for at du spør! En oppfølgingsstudie om kunnskap om vold og seksuelle overgrep mot barn blant blivende barnevernspedagoger, grunnskolelærere og førskolelærere [«Thank you for asking!» A follow up-study on knowledge about violence and child sexual abuse among future child protection workers, elementary school teachers and preschool teachers]. 2016. Available from: https://www.nkvts.no/content/uploads/2016/02/Rapport_ NKVTS_3_2016_nett.pdf. Accessed November 30, 2021.

49. Kimber M, McTavish JR, Vanstone M, Stewart DE, MacMillan HL. Child maltreatment online education for healthcare and social service providers: implications for the COVID-19 context and beyond. Child Abuse Negl. 2021;116:104743. doi:10.1016/j.chiabu.2020.104743

50. Clancy A, Olaso EM, Larkin P, Brenner M. Education on childrens complex care needs in general nursing curricula in Europe: an inductive content analysis. Nurse Educ Pract. 2021;52:103034. doi:10.1016/j.nepr.2021.103034

51. Lov om endringer i velferdstjenestelovgivningen (samarbeid, samordning og barnekoordinator). Lovdata; 2021. Available from: https://lovdata.no/dokument/NL/lov/2021-06-11-78. Accessed December 10, 2021.

52. World Health Organization. Framework for action on interprofessional education \& collaborative practice; 2010. Available from: https://apps. who.int/iris/bitstream/handle/10665/70185/WHO_HRH_HPN_10.3_ eng.pdf;jsessionid=6404FD35BF759397105FD11F092CD504? sequence $=1$. Accessed November 30, 2021.

53. INTERACT. INTERACT (Interprofessional Interaction with Children and Youth). Available from: https://uni.oslomet.no/interact/ . Accessed October 07, 2021.

54. Almendingen K, Šaltytė Benth J, Molin M. Large scale blended learning design in an interprofessional undergraduate course in Norway: context description and supervisors' perspective. MedEdPublish. 2021;10(1):1. doi:10.15694/mep.2021.000162.1

55. Bronfennbrenner U. The Ecology of Human Development Experiments by Nature and Design. Harvard University Press; 1979.

56. Vygotsky LS. Mind in Society: The Development of Higher Psychological Processes. Gyldendal Akademisk; 1978.

57. Curran VR, Sharpe D, Forristall J, Flynn K. Student satisfaction and perceptions of small group process in case-based interprofessional learning. Med Teach. 2008;30(4):431-433. doi:10.1080/01421590 802047323

58. Lillejord S, Børte K. Learning and teaching with technology in higher education - a systematic review; 2018. Available from: https://www. forskningsradet.no/siteassets/publikasjoner/1254035532334.pdf. Accessed February 20, 2021.

59. Almendingen K, Molin M, Šaltytė Benth J. Large-scale blended learning design in an undergraduate interprofessional course in Norway: students' perspectives from an exploratory study. $J$ Res Interprof Pract Educ. 2021;11(1):1-26. doi:10.22230/jripe.2021v11n1a319

60. Almendingen K, Nilsen B, Kvarme L, Saltyte Benth J. Core Competencies for interprofessional collaborative practice among teacher education, health and social care students in a large scaled blended learning course. J Multidiscip Healthc. 2021;14:22 49-2260. doi:10.2147/JMDH.S325086
61. Foss C, Guldbrandsen LM, Løndal K, Ulleberg I, Ødegaard NB, Øien I. Constructing interprofessional education: the case of INTERACT (Interprofessional Interaction with Children and Youth). Presented at: Its 21 th conference on interdisciplinary teamwork skills for the 21st century; 2018. Available from: https://www.ntnu.no/videre/konferanse/Its21/ abstractbook.pdf. Accessed November 30, 2021.

62. Evans L, Vanden Bosch ML, Harrington S, Schoofs N, Coviak C. Flipping the classroom in health care higher education: a systematic review. Nurse Educ. 2019;44(2):74-78. doi:10.1097/nne.0000000 000000554

63. The Norwegian Directorate for Children. Parents' everyday life. Safe advice for you with children. Available from: https://www.bufdir.no/ Foreldrehverdag/. Accessed November 30, 2021.

64. The Ombudsperson for children i Norway. The childrens rights poster. Available from: https://www.subjectaid.no/storage/ma/ ff 5 c 65 c 67 f 0 c 4 b 43 aae 5 e 8 b 1 ad 79151 a/ 23 d 17 d 742 e $9 d 47 f$

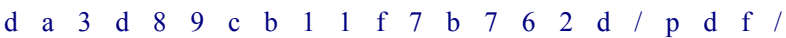
BC363FD54A3ED3ECED13B291DD705E0B8618F124/ Rettighetsplakaten.pdf. Accessed September 13, 2021.

65. Nordic 0-24 collaboration. Available from; https://0-24-samarbeidet. no/nordic-0-24-collaboration/. Accessed August 28, 2021.

66. Almendingen K, Bergem AK, Sparboe-Nilsen B, Kvarme LG, Šaltytė benth J. Children as next of kin in higher education: an exploratory cross-sectional study among health, social care, and teacher education programs. J Multidiscip Healthc. 2021;14:3295-3308. doi:10.2147/ JMDH.S338686

67. Ungdata; 2019. Available from: http://www.ungdata.no/English. Accessed October 31, 2019.

68. Nettskjema. University of Oslo. Available from: https://www.uio.no/ english/services/it/adm-services/nettskjema/. Accessed June 21, 2021.

69. Almendingen K, Molin M, Šaltytė Benth J. Preparedness for interprofessional learning: an exploratory study among health, social care, and teacher education programs. J Res Interprof Pract Educ. 2021;11 (1):1-11. doi:10.22230/jripe.2021v11n1a309

70. Oslo Metropolitan University (OsloMet). Ethical guidelines for research at Oslo Metropolitan University (OsloMet). Available from: https://ansatt.oslomet.no/documents/585743/53632647/Ethical +Guidelines+for+Reserach+at+OsloMet/3dccee65-e17e-04f6-34d3a8e 58f280c88. Accessed June 21, 2021.

71. Database for Statistics on Higher Education (DBH). Available from: https://dbh.nsd.uib.no/statistikk/rapport.action?visningId= $234 \&$ visKode $=$ false $\&$ admdebug $=$ false $\&$ columns $=$ arstall! 8 !finmodko de\&index $=1 \&$ formel=999\&hier=insttype! 9 ! instkode!9!progkode!9! emnekode\&sti=\&param=arstall\%3D2020!9!Semester\%3D3!9!dep id\%3D1!9!nivakode\%3DB3!8!B4!8!HK!8!YU!8!AR!8!LN!8!M2!8! ME!8!MX!8!HN!8!M5!8!PR. Accessed January 20, 2021.

72. The health personnel act; 2000. Available from: https://www.regjerin gen.no/no/dokumenter/act-of-2-july-1999-no-64-relating-to-hea/ id107079/. Accessed December 10, 2021.

73. The Ombudsperson for Children in Norway. NHRI report to Norway's fifth and sixth periodic report to the UN committee on the rights of the child; 2019. Available from: http://barneombudet.no/wp-content /uploads/2017/10/The-Ombudsman-for-Children-in-NorwaySupplementary-Report-to-UN-2017.pdf. Accessed October 03, 2019.

74. Boullier M, Blair M. Adverse childhood experiences. Paediatr Child Health. 2018;28(3):132-137. doi:10.1016/j.paed.2017.12. 008

75. Ministry of Education and Research. The school of the future: renewal of subjects and competences. Official Norwegian Reports NOU; 2015: 8. Available from: https://www.regjeringen.no/contentas

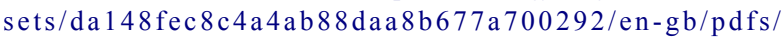
nou201520150008000engpdfs.pdf. Accessed November 30, 2021.

76. Blue Cross Norway - Let children be children.Blue Cross Norway . Available from: https://www.youtube.com/watch?v=_C58MN9n9LQ. Accessed September 17, 2021. 
77. Next of Kin Programme. Children as next of kin. Available from: https://www.youtube.com/watch?v=w_itC3Lx_6o. Accessed August 28, 2021.

78. NICE. Child maltreatment: when to suspect maltreatment in under 18s. Clinical guideline [CG89]. Available from: https://www.nice.org. uk/guidance/cg89. Accessed September 03, 2021.

79. RVTS - Regionalt ressurssenter om vold, traumatisk stress og selvmordsforebygging. Available from: https://www.snakkemedbarn. no/Accessed November 30, 2021.

80. Baugerud GA, Johnson M, Røed S, et al. Multimodal virtual avatars for investigative interviews with children. Presented at: ICDAR ' 21 : Proceedings of the 2021 Workshop on Intelligent Cross-Data Analysis and Retrieval; 2021. https://dl.acm.org/doi/pdf/10.1145/ 3463944.3469269. Accessed October 10, 2021.

81. Quality culture in higher education; 2017. Available from: https:// www.regjeringen.no/en/dokumenter/meld.-st.-16-20162017/ id2536007/. Accessed December 10, 2021.

82. Aase I, Aase K, Dieckmann P. Teaching interprofessional teamwork in medical and nursing education in Norway: a content analysis. $J$ Interprof Care. 2013;27(3):238-245. doi:10.3109/13561820.20 12.745489

83. Ministry of Education and Research. National curriculum regulations for Norwegian health and welfare education (RETHOS). Available from: https://www.regjeringen.no/en/topics/education/highereducation/nasjonale-retningslinjer-for-helse-ogsosialfagutdanningene-rethos/id2569499/. Accessed August 27, 2021.

84. European report on preventing child maltreatment; 2013. Available from: https://www.euro.who.int/__data/assets/pdf_file/0019/217018/ European-Report-on-Preventing-Child-Maltreatment.pdf. Accessed September 23, 2021.
85. Cappa C, Jijon I. COVID-19 and violence against children: a review of early studies. Child Abuse Negl. 2021;116(Pt2):105053. doi:10.1016/j.chiabu.2021.105053

86. Sandvik KB, Köhler-Olsen J. Children in lockdown: children's rights, Covid-19 and the case of Norway. PRIO Blogs blog; 2020. Available from: https://blogs.prio.org/2020/07/children-in-lockdown-childrensrights-covid-19-and-the-case-of-norway/. Accessed September 15, 2021.

87. Augusti E-M, Sætren SS, Hafstad GS. Violence and abuse experiences and associated risk factors during the COVID-19 outbreak in a population-based sample of Norwegian adolescents. Child Abuse Negl. 2021;118:105156. doi:10.1016/j.chiabu.2021.105156

88. Albaek AU, Kinn LG, Milde AM. Walking children through a minefield: how professionals experience exploring adverse childhood experiences. Qual Health Res. 2018;28(2):231-244. doi: $10.1177 / 1049732317734828$

89. A good childhood lasts a lifetime (Norwegian Ministry of Children, Equality and Social Inclusion); 2014. Available from: https://www. regjeringen.no/contentassets/e11e6a93bb274f0aaa06d469baef7d82/q1226_a-good-childhood-lasts_web.pdf. Accessed December 10, 2021.

90. The Norwegian Agency for Quality Assurance in Education. The students' judgement. Available from: https://www.nokut.no/en/news/ the-students-judgement/. Accessed September 09, 2019.

91. Morton SMB, Bandara DK, Robinson EM, Carr PEA. In the 21st century, what is an acceptable response rate? Aust $N Z \mathrm{Z}$ Public Health. 2012;36(2):106-108. doi:10.1111/j.1753-6405.2012.00854.x

92. Hsieh H-F, Shannon SE. Three approaches to qualitative content analysis. Qual Health Res. 2005;15(9):1277-1288. doi:10.1177/ 1049732305276687
Journal of Multidisciplinary Healthcare

\section{Publish your work in this journal}

The Journal of Multidisciplinary Healthcare is an international, peerreviewed open-access journal that aims to represent and publish research in healthcare areas delivered by practitioners of different disciplines. This includes studies and reviews conducted by multidisciplinary teams as well as research which evaluates the results or conduct of such teams or healthcare processes in general. The journal covers a very wide range of areas and welcomes submissions from practitioners at all levels, from all over the world. The manuscript management system is completely online and includes a very quick and fair peer-review system. Visit http://www.dovepress.com/testimonials. php to read real quotes from published authors. 